
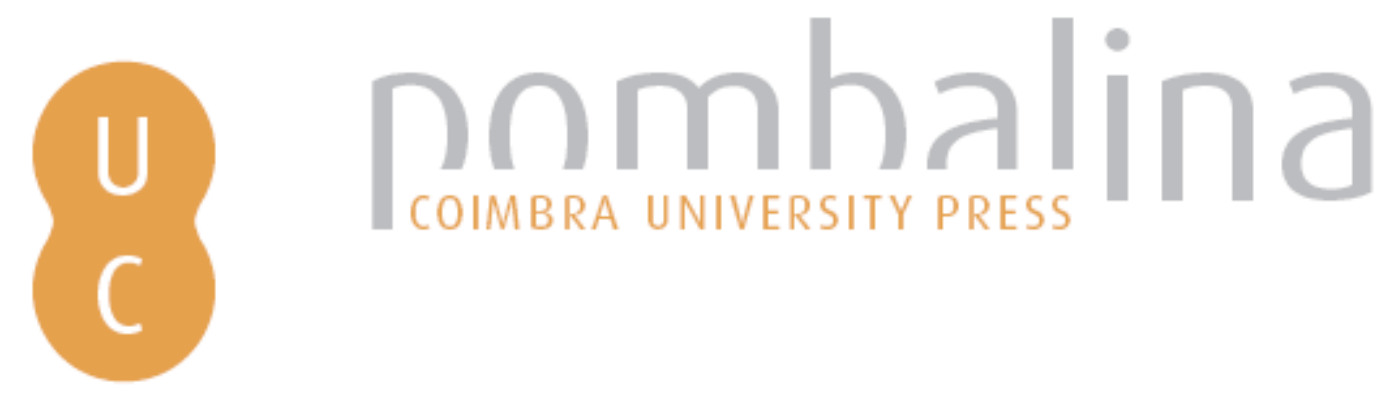

\title{
Between indian tradition and corbusian modernity: the case of the villa hutheesing- shodhan
}
Autor(es):
Candela Suárez, Maria
Publicado por: Imprensa da Universidade de Coimbra
URL
persistente:
URI:http://hdl.handle.net/10316.2/41612
DOI:
DOI:https://doi.org/10.14195/978-989-26-1338-3_9
Accessed : $\quad$ 26-Apr-2023 00:11:28

A navegação consulta e descarregamento dos títulos inseridos nas Bibliotecas Digitais UC Digitalis, UC Pombalina e UC Impactum, pressupõem a aceitação plena e sem reservas dos Termos e Condições de Uso destas Bibliotecas Digitais, disponíveis em https://digitalis.uc.pt/pt-pt/termos.

Conforme exposto nos referidos Termos e Condições de Uso, o descarregamento de títulos de acesso restrito requer uma licença válida de autorização devendo o utilizador aceder ao(s) documento(s) a partir de um endereço de IP da instituição detentora da supramencionada licença.

Ao utilizador é apenas permitido o descarregamento para uso pessoal, pelo que o emprego do(s) título(s) descarregado(s) para outro fim, designadamente comercial, carece de autorização do respetivo autor ou editor da obra.

Na medida em que todas as obras da UC Digitalis se encontram protegidas pelo Código do Direito de Autor e Direitos Conexos e demais legislação aplicável, toda a cópia, parcial ou total, deste documento, nos casos em que é legalmente admitida, deverá conter ou fazer-se acompanhar por este aviso.

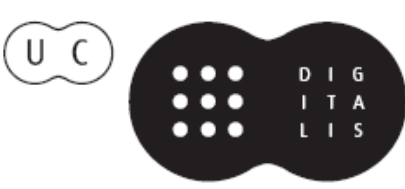


Ivan Zaknic

Arthur Rüegg

David Leatherbarrow

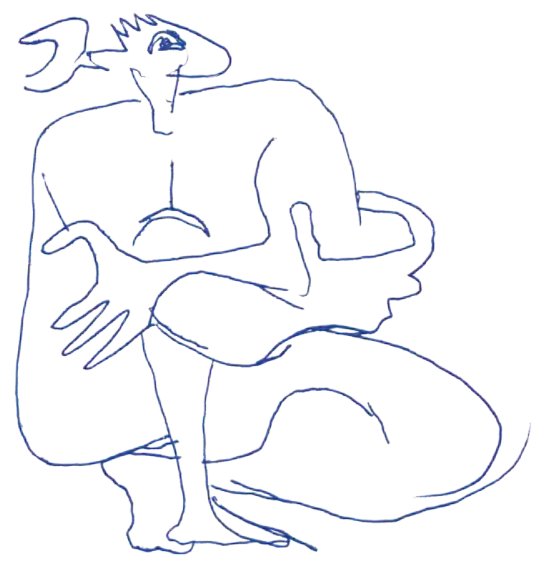

Christoph Schnoor

Francesco Passanti

Johan Linton

Stanislaus von Moos

Maria Candela Suárez

\section{Le Gorbusier}

\section{HISTORY TRADITION}

Edited by

Armando Rabaça 


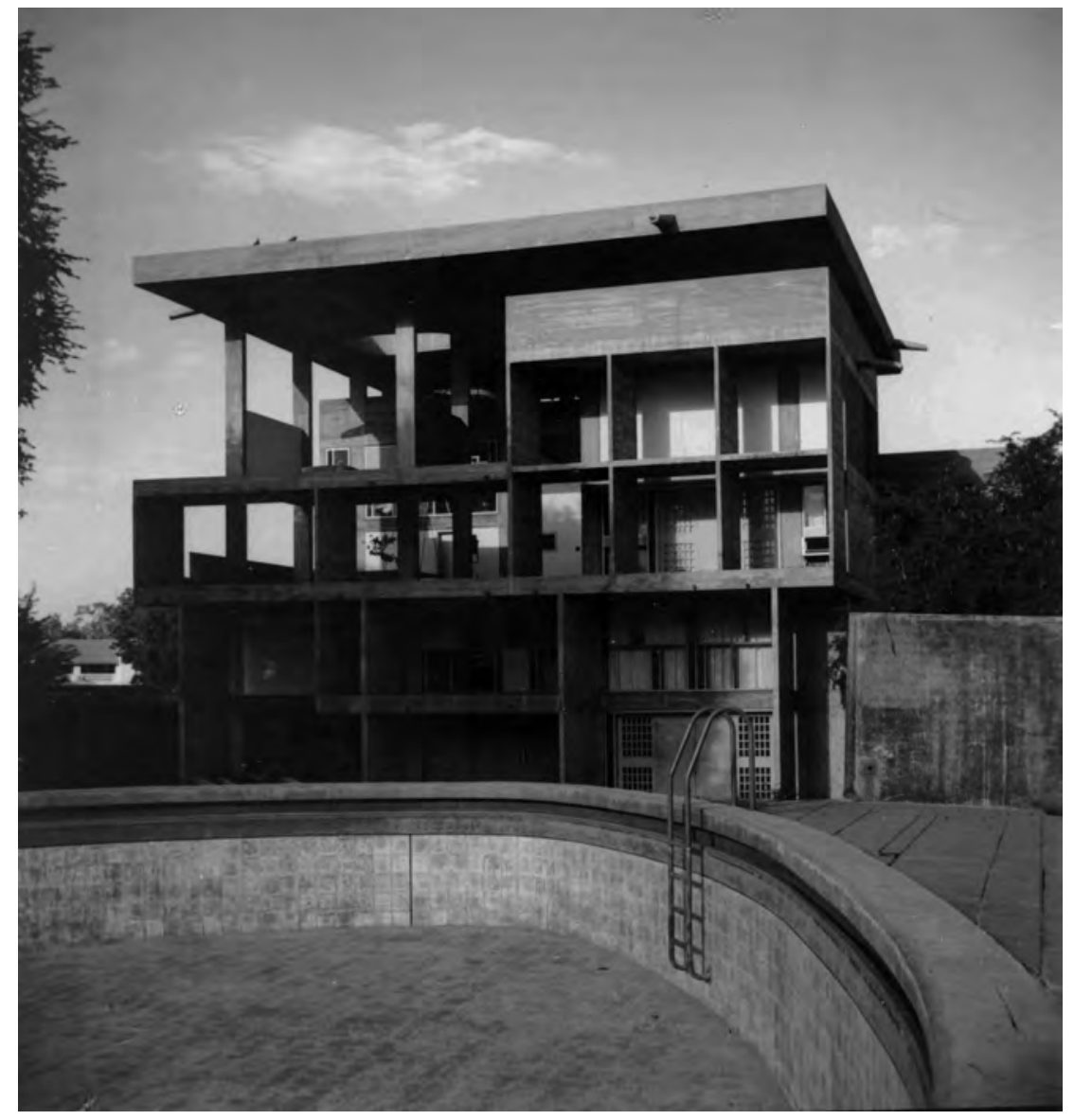

1. Villa Hutheesing-Shodhan, 1951-56. South-west elevation. 


\section{BetweEn INDIAN TRADITION AND}

\section{Corbusian Modernity:}

\section{The Case of the Villa Hutheesing-Shodhan}

In early 1951 Le Corbusier was commissioned by the Government of the State of Punjab to plan a new Capital. When he was in Chandigarh, a group of Jainist clients from Ahmedabad invited him to develop five projects, the museum of Ahmedabad, the Mill Owners' Association and three family houses. ${ }^{1}$ Four among the five were built, one of which was the Villa Hutheesing-Shodhan (Figs. 1-3). The villa is the last referent of Corbusian family-housing architecture. Developed between 1951 and 1956, it was conceived on the basis of a conscious combination of modern architecture and the climate and culture of India.

Le Corbusier's design for the Villa Shodhan-from here on referred to as Villa Hutheesing or Hutheesing-Shodhan ${ }^{2}$ — has three versions, which synthesize the vast investigation he developed over three years. ${ }^{3}$ The program for the villa is described on a sheet dated 23rd March 1951, titled "Bungalow de Surottam P. Hutheesing, Shahibag, Ahmedabad."4 It reveals the importance of building verándahs and terraces, on every floor, which would serve each bedroom so that one could sleep outside during summer nights. Among the handwritten notes, possibly expressing Hutheesing's request, Le Corbusier wrote: "very best modern (très bon modern)." This suggests the client's receptiveness to Corbusian architecture. Referring to the villa, Le Corbusier wrote in Euvre Complète: 

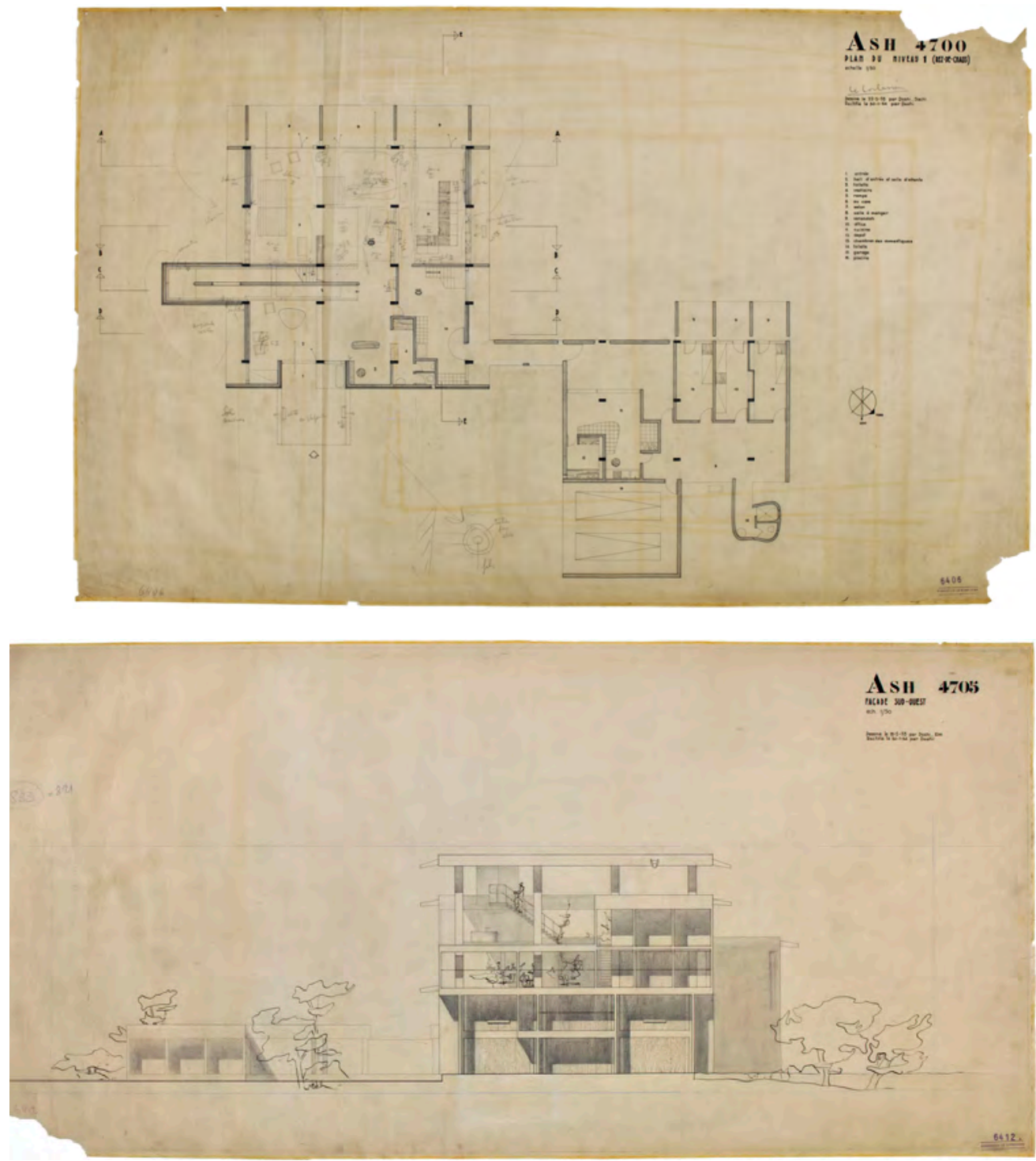

Villa Hutheesing-Shodhan, 1951. Third version.

2. Ground floor plan.

3. South-west elevation. 
The villa has a story: the commission was given to Le Corbusier in 1951 for the residence of a Mr. Hutheesing, Secretary of the Mill Owners', with a set of requirements, primarily personal, complicated and subtle. Just when the construction plans were completed, Mr. Hutheesing there upon sold them to Mr. Shodhan, who owned another plot and desired to start construction immediately. As luck would have it, Le Corbusier's Indian projects are always dictated a priori by the Indians. The transfer of this house to a new plot was therefore a perfectly natural event. ${ }^{5}$

For Le Corbusier, the Indian climate explains why Shodhan had bought the project without asking for any changes. Peter Serenyi provides more clues:

The old town house of the Shodhan family located at the heart of the city provides an interesting clue to an understanding of the client's willingness to accept Le Corbusier's design exactly as it was intended for Surottam Hutheesing. Having been raised in a house which had pilotis, terraces, roof gardens, and open façades, Shiamubhai Shodhan must not have found the designs for the house he was to buy too unusual. Coming from such an architectural environment, he was in fact better prepared to accept Le Corbusier's ideas, than a Parisian client. ${ }^{6}$

According to Serenyi, some features of the project would have been familiar to Shodham given the affinities with the traditional architecture of the city. This is the case of the double-height living room: "When Shiamubhai Shodhan first saw the designs for the double-storied interiors of his future house, he must have recognized in them a modern reinterpretation of a familiar symbol of status and wealth." 7 The same applies to the doubleheight salle d'attente:

The large houses of old Ahmedabad were usually built around a double-storied entry hall, or chowk, which signifies their symbolic and ceremonial centre. As 
Between Indian Tradition and Corbusian Modernity

seen in the eighteenth-century Chunilal house, this space was given the greatest artistic attention in terms of spatial organization and decorative treatment. ${ }^{8}$

While double-height rooms were commonly used in Le Corbusier's work, Serenyi's observations seem to suggest that the Villa Hutheesing-Shodhan entails a dialogue between Le Corbusier's modern architecture and Indian architectural tradition. My aim is to explore this dialogue. By focusing of the verándahs and terraces, I will suggest that Le Corbusier reinterpreted modern architecture through Indian architectural tradition, and that these reinterpretations became key elements of his domestic architecture in Ahmedabad.

\section{Le Corbusier and the Indian Idea of Vérandah}

For Le Corbusier, India's climate was a main concern from the beginning. When he presented the architectural solutions for the new capital of India, he cautioned in "Chandigarh. La naissance de la nouvelle capitale du Punjab (Indes) 1950":

The problem is accentuated by the ruling factor of the sun, under which this new Indian way of life must be created. The sun is so violent that until now the habits of siesta and laziness were inevitable, in native architectural conditions which allowed no work whatsoever at certain hours and seasons. The rainy season also has its problems. ${ }^{9}$

Le Corbusier paid special attention to local architecture, having found in the vérandah one of its most fundamental elements. This is shown in his notes and drafts: "The vérandah (Indian word) is the dwelling condition itself . . . One sleeps at night on the roof from April to October, except during July and August $=$ rain / one sleeps in the vérandahs." ${ }^{\prime 10}$

Several months after his first visit to India - and after having finished 
the first version of the Villa Hutheesing, which provided each floor with vérandahs - he was still reflecting on this element of Indian architecture. Next to a sketch of the façade and section of a building (Fig. 4), he explains: "The face of the verándahs results in a wall, not in pillars. But everything is approximated and Vignola." 11 In another note, he observes:

The villas and aligned houses of Delhi are a charming coquetry (Bd were the Hotel Ambassador is). But the sun does what it wants. It is necessary to start from the 4 orientations off Thapar and create what is needed: what is indispensable: subjects of the sun with the available techniques. ${ }^{12}$

From the first moment, Le Corbusier understood the value of the vérandah for Indian climate and culture. Yet, he also recognized the architectural possibilities it created: a transitional space, a void generating light and dark, an element capable of being reworked and integrated into the message he intended to pass on to the Indians, translated into modern architectural language. Thus he explored it in Hutheesing's house. In this villa, the vérandah is a key element of architectural form that invigorates its volume. The way it is adapted to all versions of the villa during the design process is clear evidence of how Le Corbusier regarded the vérandah from the beginning as an ally and not an obstacle, repeatedly taking advantage of it. Le Corbusier's notes on Indian miniatures (Figs. 5, 6) confirm - as noted by several authors - his admiration for the way in which they generate depth, light and shadow. ${ }^{13}$ One of two drawings reads: "miniatures / the modulating niche [?] This confirms the theme of the villa for Mayor Ahmedabad."14

The attributes of Indian miniatures seem to be reinterpreted at different levels in the Villa Hutheesing-Shodhan. A first level lies, as suggested in the note mentioned above, in the "alveolus" of the brise-soleil of the southwest façade $(2.26 \times 2.26 \mathrm{~m})$, providing the interior spaces and the suspended garden with a new veiling texture. A second level is suggested by Balkrishna Doshi: the connection between Indian miniatures and the concrete texture of the brise-soleils, enhancing depth through the use of a diagonal, textured 


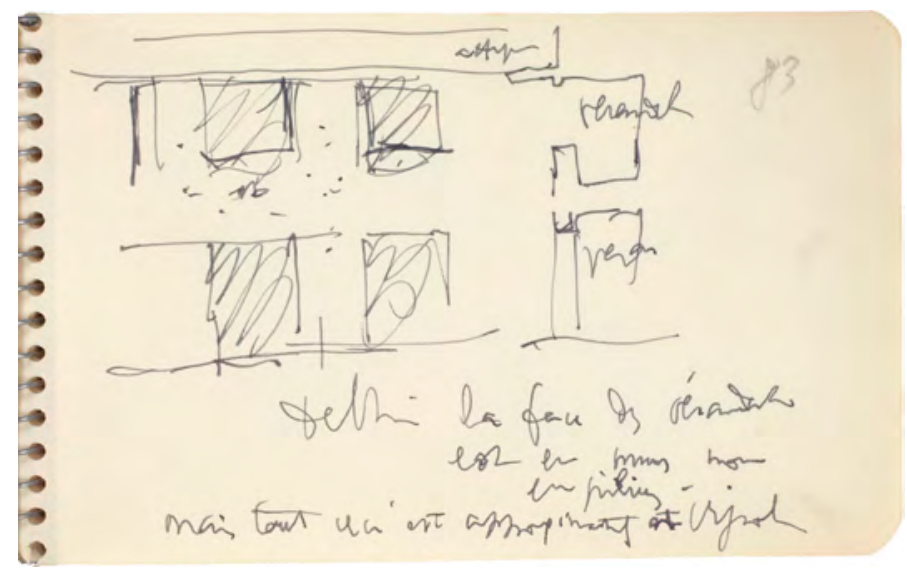

4. Le Corbusier.

Sketch of a house,

Façade and cross-section, 1951.

Carnet E23, 83. 

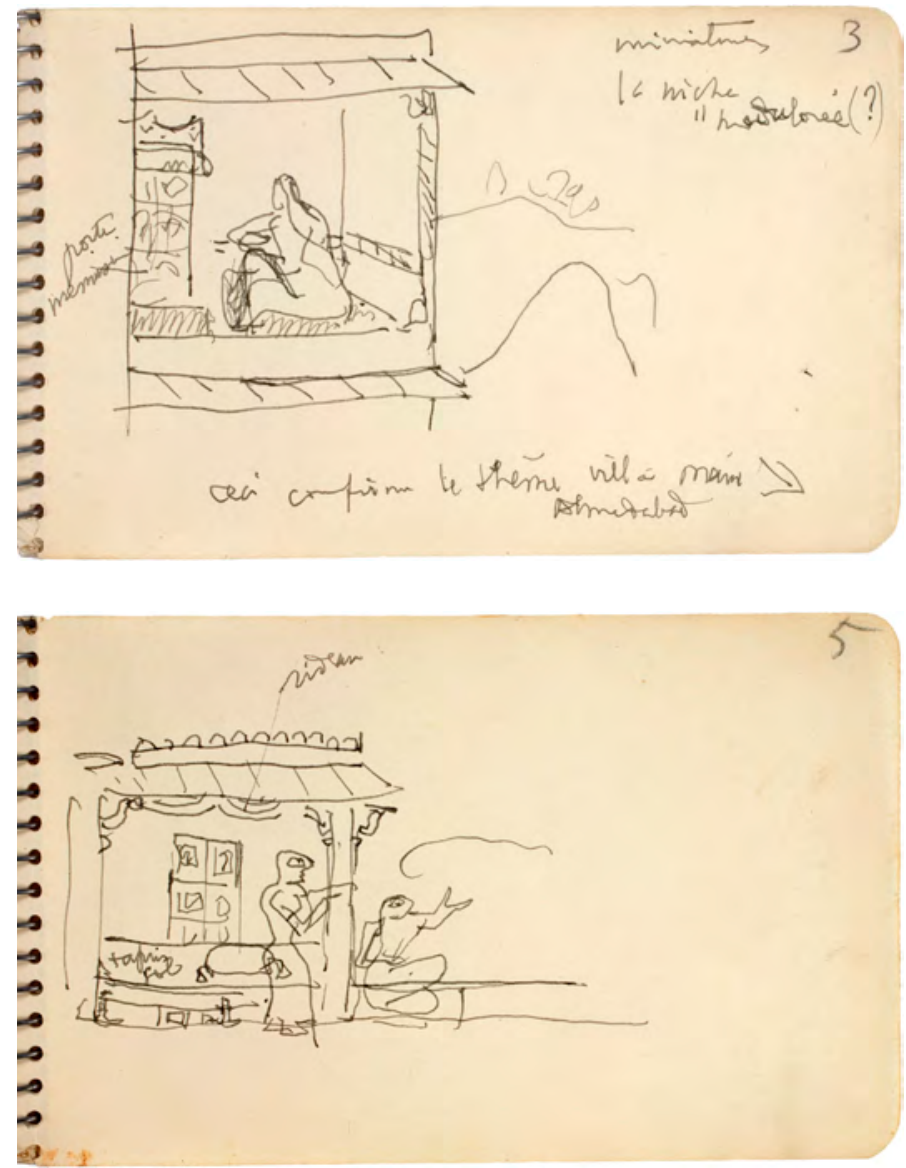

5. Le Corbusier.

Sketch of Indian miniature, 1951.

Carnet E23, 3.

6. Le Corbusier.

Sketch of Indian miniature, 1951.

Carnet E23, 5. 
formwork. ${ }^{15} \mathrm{~A}$ third level concerns the association between the spatial quality of Indian miniatures and the spatial complexity of the suspended garden, with its various platforms and stairs.

\section{Fist Level: the Alveolar Brise-SoleiL}

The brise-soleil in the Villa Hutheesing-Shodhan (Figs. 1, 3) shows a direct relationship with the alveolar façade of the Unité d'habitation in Marseilles (Fig. 7$)^{16}$ and, before that, with the façade of the Law Court in Algiers. Le Corbusier had used the brise-soleil in some of his previous projects, but it was with these two cases that it gained a new dimension.

In cases such as the Maison Curutchet (Fig. 8) or the Manufacture in Saint-Dié, the depth of the brise-soleil was reduced to the required needs of protection from the sun. The Unité d'habitation develops a new kind of brise-soleil, in which depth becomes a dominant dimension, acquiring greater formal protagonism than in the earlier cases. This was turned into a new design tool to be applied in other projects simply by adjusting its height and width to the spaces that it would protect. In the Villa Hutheesing-Shodhan, the "inhabitable alveolus" of the brise-soleil generates a textural structure in front of the interior spaces and suspended garden, veiling the inner and outer spaces. In contrast with the Unité d'habitation, the brise-soleils of the Villa Hutheesing-Shodhan are separated from the building itself, manifesting their independence. They have $2.26 \times 2.26 \mathrm{~m}$, a measure of the Modulor that Le Corbusier had recognized in the alveolus of the Indian miniature that he drew in his sketchbook E23 (Fig. 5). The Indian version of the alveolar brise-soleil can thus be seen as a three-dimensional repetition of the alveolus represented in Indian miniatures. 


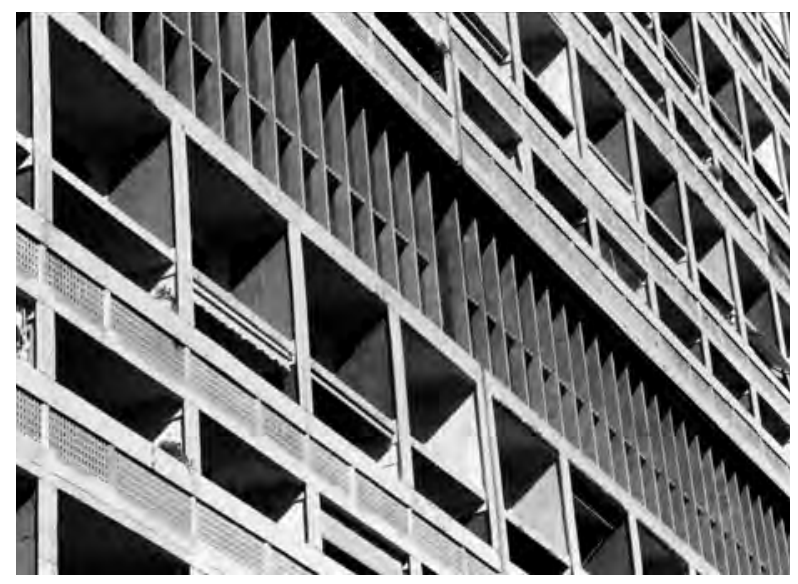

7. Unité d'habitation, Marseilles, 1947-49.

"Brise-soleil en alvéoles."

Photo: Paul Kozlowski, detail.

8. Maison Curutchet, La Plata, 1949.

Conventional brise-soleil.

Photo: Olivier Martin-Gambier, detail.

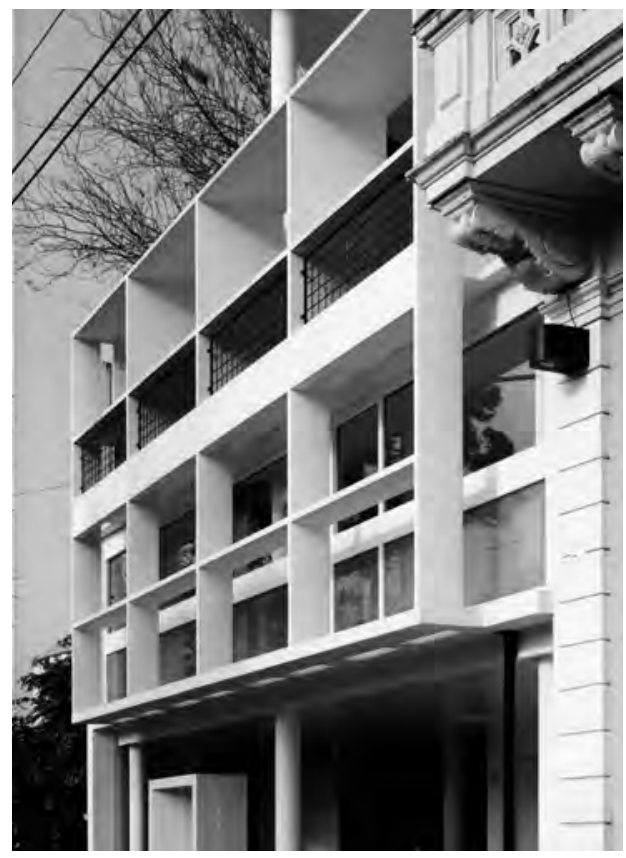


Between Indian Tradition and Corbusian Modernity

Segond Level: the Texture of the Brise-Soleil

When questioned about the impact of India on Le Corbusier's work, Doshi answered:

Well, mainly that he was looking at things in a different way than he had in the West. What do you do in a country where there's no technology but lots of skilled people, people with ideas; a country far behind in time but also very vital - full of energy! He began to think of using natural materials in a different way. When he came to Ahmedabad in 1951 and he saw the concrete column at Kanvinde's ATIRA building, I know that he took pictures, back to Paris and said: 'why not use concrete like this?'17

Doshi knows that Le Corbusier did not discover rough concrete in India. He had already used it before. In India, however, he learned how to take further advantage of its texture and plasticity.

No, not really discovered-Marseilles had already been in rough concrete. But we had to do the form-work in small plates, because pouring and casting is difficult. And he said, 'why not take planks and do what we call shuttering?'. He also used steel form-work and said 'why don't we show the rivets also so we can feel how the concrete is poured.' In India he looked at concrete as texture. What he did here was to add plasticity. Le Corbusier was a man of great plasticity. ${ }^{18}$

So, he explains how, feeding upon the Indian miniatures he had drawn, Le Corbusier attempted to intensify the visual depth of concrete:

He spent a lot of time looking at Indian miniatures and he once showed me a painting of Krishna and Radha dancing and he said, 'You see, how front and back are shown, how you can twist the plane to get a complete image.' The problem that was intriguing him was how to get another dimension within the 
same plane. And this is what he did in Ahmedabad, he made the form-work go against the nature of concrete, i.e., normally the form-work is designed vertically, but here he placed the shuttering planks diagonally, so that the shadows cast are diagonal, while the basic level remained horizontal. This was done with the idea that the plane must get another dimension through shadow. So he discovered that you can use planes in a different way. No one really invents, you know, only re-discovers. ${ }^{19}$

In the Villa Hutheesing-Shodhan (as in the Mill Owners' Association, the two projects of Ahmedabad where rough concrete acquires greater expression) the concrete texture is vertical and horizontal, never diagonal. Concrete texture does not lack purpose, however. When the form-work footprint is horizontal, it accentuates the depth of the brise-soleil and extends the length of the façades. In contrast, when the footprint is vertical, it emphasizes the strength of the load-bearing elements.

Third Level: the Spatiality of the Suspended Garden and Traditional Indian Terrages

The Indian miniatures seem to have awakened in Le Corbusier another architectural aspect: the new spatiality that his concept of suspended garden could acquire, a spatiality now multiplied in platforms of different levels, connected by stairs just as in traditional Indian architecture (Figs. 9-12). This new conception of the suspended garden can be found from the beginning of the design process to the built version.

Various authors, including Le Corbusier himself, compared the Villa Hutheesing-Shodhan with Villa Savoye. Some of them, as Prasad and others, have argued that a shortfall of the Indian villa resides in the interruption of the ascending path along the ramp, ending on the first floor. It is further argued that the specific problem of the ramp is that the end occurs at a small and secondary point: the first floor hall. One must however ask how the Villa 
Between Indian Tradition and Corbusian Modernity
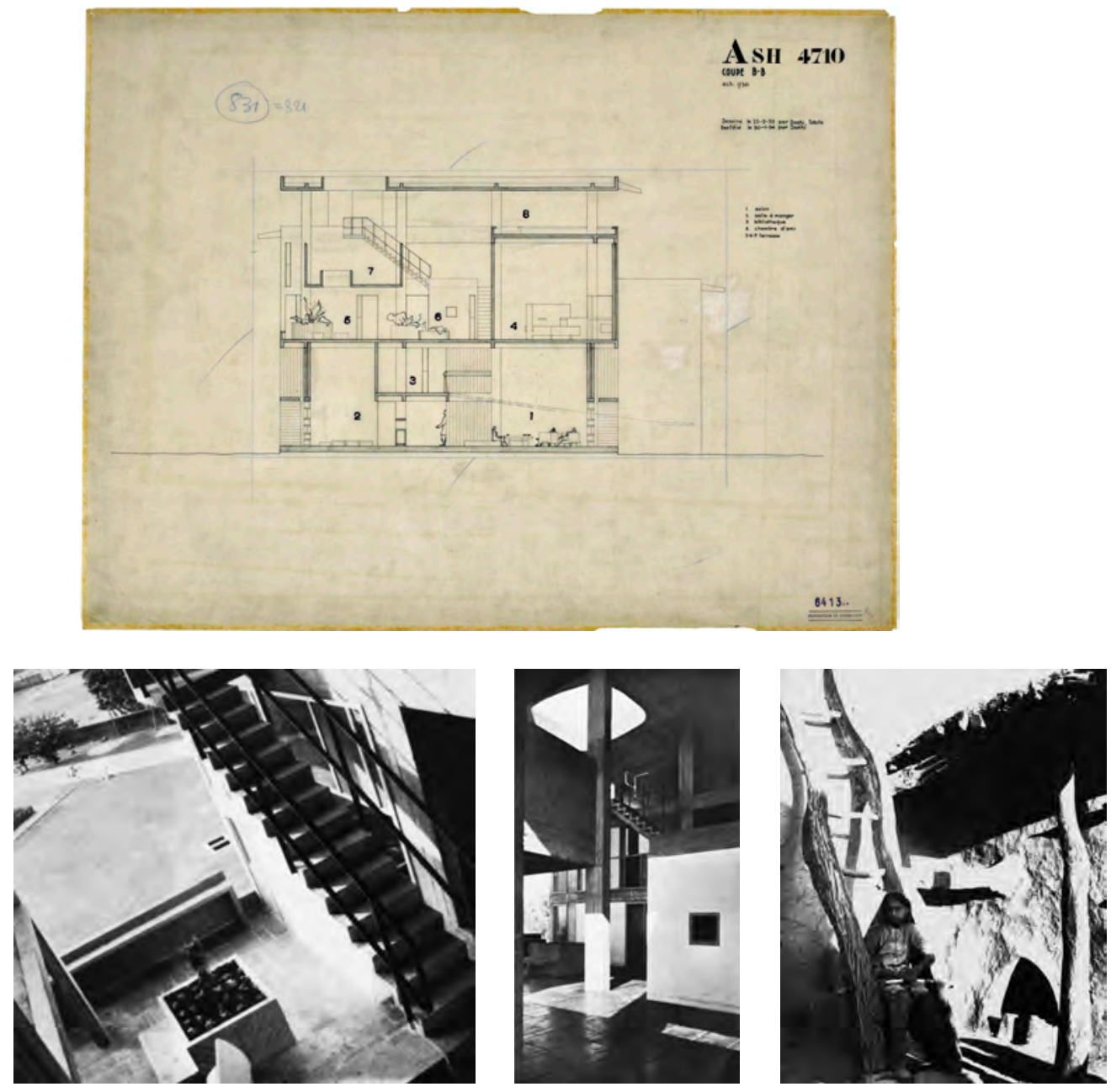

Villa Hutheesing-Shodhan.

9. Section across the suspended garden with the ramp leading to the first floor.

10. Suspended garden from level 2bis.

From Euvre complète, 1952-1957.

11. Suspended garden and sunshade.

From Euvre complète, 1952-1957.

12. Traditional Indian architecture.

Courtyard with ladder to the roof terrace.

From Euvre complète. 1965-1969. 
Hutheesing-Shodhan should be looked at in light of VillaSavoye, with the end of its journey at the toit-jardin, facing a window framing the landscape.

This questionable comparison seems to rest on the premise that both villas take into consideration the surrounding natural environment in the same way. This, I think, is not the case. Whereas the Villa Savoye struggles against nature, considers it antagonist to architecture, is overwhelmed by it, and only manages to counterpoise its strength and order at the end of the path through the window on the toit-jardin, the Villa Hutheesing-Shodhan dialogues with its natural environment as an equal. This is because Le Corbusier did not feel here the harassment that Western nature imposed in the 1920s. Unravelling the issue is necessary to understand Le Corbusier's position with regard to nature when he designed these two projects, distant from each other by over thirty years.

In Vers une architecture, Le Corbusier had written: "A house that will be this human boundary that encloses us from antagonistic natural phenomena, giving us, giving man, our human milieu." ${ }^{20}$ In Almanach d'architecture moderne, he added:

What do you see developing before your eyes, if not an immense setting in order? Fighting against nature to dominate it, to classify it, to profit from it, in a word, to settle oneself in a human world that is not the milieu of antagonistic nature, a world of our own, of geometric order? ${ }^{21}$

For Le Corbusier, in the 1920s, nature meant chaos, and only architectural order could neutralize its negative effects, tame it with its geometrical laws to reverse the relationship of domination. It is the window at the end of the path that organizes the initial chaos in every suspended garden of the 1920s:

Because it is in the window that nature becomes landscape, where the ultimate focus of the path is to be found, the episode that puts an end to representation, where the initial antagonism between nature and man is overcome, fusing both characters. $^{22}$ 
The impact of what he saw after reaching India, however, led Le Corbusier to recognize the need for reconciliation with nature which he once considered antagonist, the need to make a pact with it:

He saw many things for the first time, the bright blue sky, the relentless sun, the hot winds, the cool moon, the beauty of tropical nights, the fury of the monsoon, and he said to me once that while his work so far had been a counterpoint to nature, he now realized that he had to make a pact with nature..$^{23}$

In comparing the Villa Savoye and Villa Hutheesing-Shodhan, it is possible to argue that in the latter, the ramp reaches the point it should reach. There is no path end. Neither is there a window framing nature. There is no such window because nature is no longer a chaotic entity for Le Corbusier to tame. Instead, there is: a suspended garden deployed across multiple platforms topping the villa, multiple path endings, and various windows (Figs. 9, 10). There is a ramp that has expanded into multiple steps through which the continuity of the climb to the toit-parasol is assured. In reality, the ascent provided by the villa is achieved through the conjunction of the ramp, the roofs of the inner spaces, and stairs. It is this conjunction that guarantees the path, which is not linear, as in the 1920s, but zigzagging, with intermittent openings and closures, full of events. Only through the platforms that cover the inner spaces, in the suspended garden, is it possible to reach the stairs, which, reinterpreting the ladder of traditional Indian architecture, serve to reach the toit-parasol, even if the main spaces remain underneath, protected from the Indian sun. 


\section{Conclusion}

A cross-reading of the Villa Hutheesing-Shodhan, combining the principles of modern Corbusian architecture with Indian tradition, allows us to understand the relevant experience that building in India meant to Le Corbusier. Knowing what Greece and the Middle East had also meant to him in his youth, Doshi wrote:

... he admired most profoundly the quality of activities around the huge water tank enclosed by the spaces and forms of the Sarkhej mosque and tomb complex. His only comment to me was 'Doshi, you do not need to go to the Acropolis, you have all that we seek from architecture. ${ }^{24}$

For Le Corbusier, India meant looking backwards into his youth and, at the same time, the confirmation of the timelessness and universality of some of the architectural tools that he had explored throughout his work. Indian tradition led him to reinterpret and re-elaborate his modern design, just as Mediterranean culture had participated in the basis of his architecture. The design of the Villa Hutheesing-Shodhan illustrates how, until the end of his life, Le Corbusier's architecture results from a continuous dialogue between tradition and modernity, allowing him to further develop the architectural elements of his researches, from the depth of the brise-soleil to the relevance of its texture, and from the spatiality of the suspended garden to the paths it generates, ultimately expressing a dialogue between architecture and nature that he had discovered forty years earlier in the Mediterranean. 


\section{Between Indian Tradition and Corbusian Modernity}

\section{Notes}

1 The museum was commissioned by the Mayor of Ahmedabad, Chinubai Chimanbhai, who also asked Le Corbusier for the design of his house. The building for the Mill Owners' Association was commissioned by Surottam Hutheesing, president of the association and Chimanbhai's cousin, who also asked Le Corbusier for the design of a house. The third house was commissioned by Manorama Sarabhai, Chimanbhai's sister. These commissions date from March 1951, during Le Corbusier's first trip to Ahmedabad, except for that of Sarabhai House, dating from November 1951, during Le Corbusier's second trip.

This paper is financed by National Funds through FCT - Foundation for Science and Technology under the project uID/HIs/04059/2013, and the European Regional Development Fund (ERDF) through the Operational Program Competitiveness and Internationalization - COMPETE 2020 (POCI-01-0145 FEDER-007460).

2 The house was designed for Surottam Hutheesing. The final plans were then sold to Shiamubhai Shodhan, Hutheesing's friend, for whom the villa was eventually built.

3 Versions are dated October 1951, November 1952 and May 1953. The first and third versions were published in volumes 5 and 6 of CEurre Complète. Nevertheless, the Registration book from the atelier reveals the existence of a fourth "avant-projet" dated June 1952 which would have been sent to Hutheesing (FLC 6445).

4 FLC P3-5-2.

5 Le Corbusier, Euvre complète 1952-57 (Zurich: Artemis, 1957), 134. The French version of this text adds more information: "Par bonheur, les projets indiens de Le Corbusier sont toujours dictés a priori par le soleil et les vents dominants qui sont constants, par régions de l'Inde. Le transfert de cette habitation sur un nouveau terrain se fit donc assez naturel."

6 Peter Serenyi, "Timeless but of its Time: Le Corbusier's Architecture in India," in Allen H. Brooks, ed., The Le Corbusier Archive: Ahmedabad, 1953-1960, Vol. 26 (New York; Paris: Garland Publishing Inc.; Fondation Le Corbusier, 1984), xvi.

7 Ibid.

8 Ibid.

9 Le Corbusier, Euvre complète 1946-52 (Zurich: Girsberger, 1953), 114.

10 "La vérandah (mot indien) est la condition même du logis . . . La nuit on dort sur le toit d'avril à octobre sauf juillet et août = pluie / on dort dans le vérandah." Le Corbusier, Album Punjab 
Maria Candela Suárez

Simla. Chandigarh, Mars 1951, 17 (FLC Archives).

11 "La face des vérandahs est en murs non en piliers. Mais tout ceci est approximatif et Vignole." Le Corbusier, Carnet E23 Indes, 1951, 27 Octobre-28 Novembre, repr. in Françoise de Franclieu, ed., Le Corbusier Carnets 2, 1950-1954 (Paris: Hercher, Dessain et Tolra, 1981), ill. 652.

12 "Les villas et maisons alignées de Delhi sont une coquetterie charmante (Bd où est l'Hôtel Ambassador). Mais le soleil fait ce qu'il veut. Il faut partir des 4 orientations off Thapar et créer ce qu'il faut: ce qui est indispensable: des sujets du soleil avec les techniques disponibles.” Ibid., ill. 653 .

13 During my research it was not possible to find information about the miniatures drawn by Le Corbusier. The figures and scenes represented lead us to suggest their relationship with the Basholi School (and even with the Mewâr School). Commissions for Ahmedabad would have led Le Corbusier to the study of this school's miniatures in the 1950s. Note that he had already shown interest in other Oriental miniatures in 1911, having bought some Persian exemplars during his journey to the East. Images of Indian miniatures can also be found in books on Indian painting belonging to Le Corbusier's personal library, although not being the ones depicted in the sketches of Carnet E23.

14 "Miniatures / la niche modulorée [?]." Ibid., ills. 611-612.

15 Balkrishna Doshi was an Indian architect who collaborated with Le Corbusier on the projects for Ahmedabad, including the Villa Hutheesing-Shodhan. Later, Doshi moved to Ahmedabad to replace Jean-Louis Véret in the building supervision. He had met Le Corbusier in London, while studying there, during the ciAm congress in Hoddesdon in 1951. He was the only Indian architect to attend the congress.

16 Le Corbusier named this façade "les brise-soleil en alvéoles."

17 Balkrishna Doshi, "Le Corbusier: The Acrobat of Architecture," interview with Carmen Kagal, in Le Corbusier and Louis Kahn. The Acrobat and the Yogi of Architecture (Ahmedabad: Vastu-Shilpa Foundation for Studies and Research in Environmental Design, 1986), 5.

18 Ibid.

19 Ibid, 5-6.

20 "Une maison qui soit cette limite humaine, nous entourant, nous séparant du phénomène naturel antagoniste, nous donnant notre milieu humain, à nous hommes." Le Corbusier, Vers une architecture (Paris: Crès, 1923), i. Translation from the English edition Toward and Architecture, transl. by John Goodman (London: Frances Lincoln, 2008), 83. 


\section{Between Indian Tradition and Corbusian Modernity}

21 "Que voyez-vous se dérouler sous vos yeux, sinon une immense mise en ordre? Lutte contre la nature pour la dominer, pour classer, pour se donner ses aises, en un mot, pour s'installer dans un monde humain qui ne soit le milieu de la nature antagoniste, un monde à nous, d'ordre géométrique?" Le Corbusier, Almanach d'Architecture Moderne (Paris: Crès, 1926), 26.

22 Josep Quetglas, Les Heures Claires. Proyecto y arquitectura en la villa Savoye de Le Corbusier y Pierre Jeanneret, sec. ed. (Barcelona: Associació d'idées. Centre d'Investigacions estetiques, 2009), 593.

23 Doshi, "Le Corbusier: The Acrobat of Architecture," 5.

24 Doshi, "Legacies of Le Corbusier and Louis I. Kahn in Ahmedabad," $A+U$, no. 368 (2001), 22. 